\title{
Electric-potential difference-a neglected parameter of gut integrity and function? ${ }^{1}$
}

Electrophysiological measurements, already established as crucial to investigation or diagnosis in other fields, may be applied increasingly to the understanding of gastrointestinal function and disease through determinations of the electric-potential difference between the gastrointestinal mucosa and serosa. The electric-potential difference is the difference between the electric potentials of two standard non-polarizable electrodes in contact with solutions on either side of a membrane, the junction potential being eliminated. In vivo, this steady potential reflects several factors, including the maintained separation of ions, the concentrations of such ions on the two sides of the membrane, and tissue resistance ${ }^{1}$; it differs from small cyclic potentials generated in smooth muscle cells. Although the precise origin of transmural electricpotential difference in the gut, and the relative influences of the physicochemical processes that modify it or are modified by it, are uncertain, the transmural electric-potential difference arises in the mucosal cells, 3, 4, 5 and represents the algebraic sum of all the potential differences across both the luminal and the serosal membranes. Striking regional differences in the electric-potential difference are found in the gastrointestinal tract, presumably because of the differing structures and functions of the mucosa at various anatomical sites. Whereas earlier studies of electric-potential difference in man yielded conflicting results, because of the use of the unabraded or variably abraded skin for the indifferent electrode, valid determinations of electric-potential difference can now be performed simply by placing the indifferent electrode in peripheral blood ${ }^{7}$, which has been shown to be equipotential with serosa ${ }^{8}$.

The electric-potential difference in the human stomach is relatively high, approximating $40 \mathrm{mv}$ in the corpus and $20 \mathrm{mv}$ in the antrum (mucosa negative to serosa) ${ }^{7}, 8$. Abrupt declines in the electric-potential difference occur when the sensing electrode is passed from the stomach to the oesophagus or duodenum, and these declines coincide with the gastrooesophageal or pyloroduodenal mucosal junctions; therefore, the electric-potential difference has been used to locate these regions for a variety of purposes $7,9,10,11,12$. Animal studies can be interpreted as showing that gastric electric-potential difference is probably generated by continuous secretion of chloride in excess of cations ${ }^{13}$, but a more direct relationship with sodium transport is not excluded ${ }^{14}$. An intact mucosa is probably essential for maintenance of normal electric-

'Some of the work described here was supported by grant AM-6908 from the Public Health Service, National Institutes of Health, USA. 
potential difference. Davenport and his colleagues ${ }^{15}$ showed that eugenol, which causes exfoliation of gastric epithelial cells, abolishes the normal barrier to diffusion of sodium and simultaneously reduces the electricpotential difference of the canine stomach. Anoxia and agents believed to be toxic to the gastric mucosa, including salicylates, alcohol, and bile, lead to a decrease in the electric-potential difference and disrupt the gastric mucosal barrier in man or animals ${ }^{8,16,17,18,19}$. Patients with pernicious anaemia have reduced electric-potential difference in the body of the stomach ${ }^{20}$, 2 , but the electric-potential difference has yet to be evaluated in man in other conditions associated with disease or damage involving the mucosa. Interestingly, gastric electric-potential difference remains unchanged during standard procedures that stimulate gastric secretion in health, except for a trivial and temporary decrease at the onset of maximal betazole stimulation ${ }^{20,22,23}$.

Relatively small transmural potential differences of 1 to $5 \mathrm{mv}$ (mucosa negative) have been measured throughout the small intestine in several species, and no regional difference has been defined ${ }^{1}$. A close relationship exists between electric-potential difference and the transport of electrically charged particles. Ussing and his associates ${ }^{24}$ first stressed that a knowledge of the magnitude and polarity of electric-potential difference is essential in determining whether ions move actively or passively, and the relationship has been validated extensively by studies of simple membranes ${ }^{25},{ }^{26}$. Thus, electric-potential difference in the small intestine is modified by, or modifies, the movement of sodium and actively transported sugars or amino acids. Decreasing the intraluminal concentration of sodium leads to the reduction of, and then the reversal in, polarity of transmural electric-potential difference, the latter change having been interpreted as reflecting a preferential leak of cations as a result of negative charges on the mucosal pores ${ }^{27}$. By contrast, glucose, other actively transported sugars, and amino acids cause a rapid increase in electric-potential difference that is unrelated to the metabolism of these compounds ${ }^{27}, 28,29,30,31,32,33$. These electrophysiological effects were once attributed solely to concomitant changes in sodium transport, but the short circuit currents exceed those expected from the measured sodium movement ${ }^{34}$, and it now appears that the disparity may be accounted for by chloride secretion into the lumen ${ }^{35}$. In healthy man and animals, potentials of about $5 \mathrm{mv}$ (mucosa negative) have been found throughout the small intestine; these potentials also increase during glucose absorption and are reduced by low concentrations of sodium in the lumen ${ }^{27}, 31,32,33,34,35,36,37,38$. The degree to which the electric-potential difference is modified by disease of the small intestine, especially those associated with disorders of ionic transport, has yet to be explored.

The relatively large potential differences (40 to $60 \mathrm{mv}$, mucosa negative) measured in the colon in various animals and in $\operatorname{man}^{5,31,39,40}$ are currently attributed to active sodium transport ${ }^{40}$, but no data are available regarding specific mechanisms or the findings associated 
with disease of the organ. Similarly, although potential differences of considerable magnitude have been recorded from the liver and pancreas in animals, and are modified by hepatic damage from carbon tetrachloride $^{41,42}$ or by pancreatic exocrine secretion ${ }^{43}$ respectively, no basic or clinical correlations of these phenomena have been sought.

It is concluded that measurement of the electric-potential difference, already essential for investigation of ionic transport and sometimes helpful in identifying anatomical junctional zones in the gut, now deserves greater application in seeking correlations between disorders, of structure and function in gastrointestinal disease.

MICHAEL G. GEALL

W. H. G. SUMMERSKILL

\section{REFERENCES}

${ }^{1}$ Schultz, S. G., and Curran, P. F. (1968). Intestinal absorption of sodium chloride and water. In Handbook of Physiology, Section 6, Alimentary Canal, edited by C. F. Code, Volume III, Intestinal Absorption, pp. 1245-1275. American Physiological Society, Washington, D.C.

${ }^{2}$ Rehm, W. S. (1946). Evidence that the major portion of the gastric potential originates between the submucosa and mucosa. Amer. J. Physiol., 147, 69-77.

${ }^{3}$ Sawyer, P. N., Rhoads, J. E., and Panzer, R. (1949). An evaluation of electrogastrography in the diagnosis of gastric cancer. Surgery, 26, 479-487.

'Villegas, L. (1962). Cellular location of the electrical potential difference in frog gastric mucosa. Biochim. biophys. Acta (Amst.), 64, 359-367.

${ }^{6}$ Edmonds, C. J. (1967). The gradient of electrical potential difference and of sodium and potassium of the gut contents along the caecum and colon of normal and sodium-depleted rats. J. Physiol.(Lond.), 193, 571-588.

'Baillien, M., and Schoffeniels, E. (1961). Origine des potentiels bioélectriques de l'épithélium intestinal de la tortue grecque. Biochim. biophys. Acta (Amst.), 53, 537-548.

'Andersson, S., and Grossman, M. I. (1965). Profile of $p \mathrm{H}$, pressure, and potential difference at gastroduodenal junction in man. Gastroenterology, 49, 364-371.

${ }^{8}$ Geall, M. G., McIlrath, D. C., Phillips, S. F., Code, C. F., and Summerskill, W. H. J. (1968). Measurement of the transmucosal potential difference of stomach in unanesthetized man. Ibid., (Abstr.), 54, 1235.

'Helm, W. J., Schlegel, J. F., Code, C. F., and Summerskill, W. H. J. (1965). Identification of the gastroesophageal mucosal junction by transmucosal potential in healthy subjects and patients with hiatal hernia. Ibid., 48, 25-35.

${ }^{10}$ Meckeler, K. J. H., and Ingelfinger, F. J. (1967). Correlation of electric surface potentials, intraluminal pressures, and nature of tissue in the gastroesophageal junction of man. Ibid., 52, 966-971.

${ }^{11}$ Greenwood, R. K., Schlegel, J. F., Helm, W. J., and Code, C. F. (1965). Pressure and potential difference characteristics of surgically created canine hiatal hernia. Ibid., 48, 602-611.

${ }^{12}$ Rovelstad, R. A., Owen, C. A., Jr., and Magath, T. B. (1952). Factors influencing the continuous recording of in situ $p \mathrm{H}$ of gastric and duodenal contents. Ibid., 20, 609-624.

${ }^{13}$ Hogben, C. A. M. (1955). Active transport of chloride by isolated frog gastric epithelium: origin of the gastric mucosal potential. Amer. J. Physiol., 180, 641-649.

${ }^{14}$ Cummins, J. T., and Vaughan, B. E. (1963). Relation of sodium to the bioelectric parameters of rat stomach. Nature (Lond.), 198, 1197-1198.

${ }^{15}$ Davenport, H. W., Warner, H. A., and Code, C. F. (1954). Functional significance of gastric mucosal barrier to sodium. Gastroenterology. 47, 142-152.

${ }^{16}$ Mislowitzer, E., and Silver, S. (1932). Uber die Potentiale der Magenschleimhaut. I. Biochem. Z., 256, 432-443.

${ }^{17}$ Quigley, J. P., Barcroft, J., Adair, G. S., and Goodman, E. N. (1937). The difference in potential across gastric membranes and certain factors modifying the potential. Amer. J. Physiol., 119, 763-767.

${ }^{18}$ Coy, F. E., Jr., Bajandas, F. J., De Graffenreid, T. P., II, and Rehm, W. S. (1951). Effect of interrupting blood flow on gastric potential and $\mathrm{HCl}$ secretion. Gastroenterology, 17, 260-268.

${ }^{19}$ Overholt, B. F., and Pollard, H. M. (1968). Acetylsalicylic acid and ionic fluxes across the gastric mucosa of man. Ibid., 54, 538-542.

${ }^{20}$ Andersson, S., and Grossman, M. I. (1966). Effects of histalog and secretin on gastroduodenal profile of $p \mathrm{H}$, potential difference, and pressure in man. Ibid. 51, 10-17.

${ }^{21}$ Katzka, I., Lemon, H. M., and Jackson, F. (1955). The correlation of human gastric potentials with gastric physiology. Ibid., 28, 717-730.

${ }^{22} \mathrm{Rehm}$, W. S. (1944). The effect of histamine and $\mathrm{HCl}$ on gastric secretion and potential. Amer. J. Physiol., $141,537-548$.

${ }^{23}$ Crane, E. E., Davies, R. E., and Longmuir, N. M. (1948). Relations between hydrochloric acid secretion and electrical phenomena in frog gastric mucosa. Biochem. J., 43, 321-336.

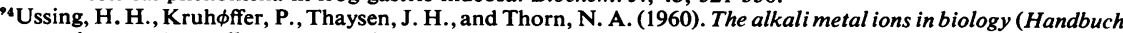
der experimentellen Pharmxkologie, edited by O. Eichler and A. Farah, Ergänzungswerk, vol. 13), p. 59. Springer, Berlin.

25 _ - and Zerahn, K. (1951). Active transport of sodium as the source of electric current in the short-circuited isolated frog skin. Acta physiol. scand., 23, 110-127.

${ }^{28}$ Leaf, A., Anderson, J., and Page, L. B. (1958). Active sodium transport by the isolated toad bladder. J. gen. Physiol., 41, 657-668. 
${ }^{27}$ Fordtran, J. S., and Dietschy, J. M. (1966). Water and electrolyte movement in the intestine. Gastroenterology, 50, 263-285.

${ }^{28}$ Barry, R. J. C., Dikstein, S., Matthews, J., Smyth, D. H., and Wright, E. M. (1964). Electrical potentials associated with intestinal sugar transfer. J. Physiol. (Lond.), 171, 316-338.

${ }^{20}$ Barry, R. J. C. (1967). Electrical changes in relation to transport. Brit. med. Bull., 23, 266-269.

${ }^{30}$ Curran, P. F, and Solomon, A. K. (1957). Ion and water fluxes in the ileum of rats. J. gen. Physiol.411, 143-158.

${ }^{31}$ Lyon, I., and Crane, R. K. (1966). Studies on transmural potentials in vitro in relation to intestinal absorption. I. Apparent Michaelis constants for $\mathrm{Na}^{+}$-dependent sugar transport. Biochim. biophys. Acta (Amst.), 112, 278-291.

${ }^{22}$ Levin, R. J., Koldovský, O., Hołková, J., Jirsová, V., and Uher, J. (1968). Electrical activity across human foetal small intestine associated with absorption processes. Gut, 9, 206-213.

${ }^{33}$ Gilles-Baillien, M., and Schoffeniels, E. (1965). Site of action of L-alanine and D-glucose on the potential difference across the intestine. Arch. int. Physiol., 73, 355-357.

s'Barry, R. J. C., Smyth, D. H., and Wright, E. M. (1965). Short-circuit current and solute transfer by rat jejunum. J. Physiol. (Lond.), 181, 410-431.

${ }^{35}$ Taylor, A. E., Wright, E. M., Schultz, S. G., and Curran, P. F. (1968). Effects of sugars on ion fluxes in intestine. Amer.J. Physiol., 214, 836-842.

${ }^{86}$ Soergel, K. H., Whalen, G. E., Geemen, J. E., and Gustke, R. F. (1966). Potential difference of the intact human intestine during active and passive transport. (Abstr.). Proc. cent. Soc. clin. Res., 39, 75.

${ }^{37}$ Grady, G., MacGaffey, K., Moore, E. W., and Chalmers, T. C. (1966). Electrophysiological properties of human intestinal segments in vitro. (Abstr.), Gustroenterology, 50, 883.

${ }^{88}$ Fordtran, J. S., Rector, F. C., Jr., and Carter, N. W. (1968). The mechanisms of sodium absorption in the human small intestine. J. clin. Invest., 47, 884-900.

${ }^{39}$ Geall, M. G., Phillips, S. F., and Summerskill, W. H. J. Unpublished observations.

${ }^{\circ 0}$ Cooperstein, I. L., and Brockman, S. K. (1959). The electrical potential difference generated by the large intestine: its relation to electrolyte and water transfer. J. clin. Invest., 38, 435-442.

"Beigelman, P. M., Coraboeuf, E., and Guilbault, P. (1964). Electrical potentials of liver. Life Sci., 3, 1343-1348.

'2Valiathan, M. S., Topaz, S. R., and Ballinger, W. F., II. (1967). Electrical activity of the canine liver. J. surg. Res., 7, 186-187.

${ }^{43}$ Anrep, G. V., and Daly, I. de B. (1921). Electrical variation of the pancreas. J. Physiol.(Lond.), 55, ii-iii. 